\title{
The Argument for Panpsychism from Experience of Causation
}

\author{
Hedda Hassel Mørch
}

The Routledge Handbook of Panpsychism (ed. William Seager), Cambridge University Press, 2019

Penultimate draft - please cite published version.

\section{Introduction}

Panpsychism is the view that all things are associated with some form of consciousness or phenomenal experience. In recent literature, panpsychism has been defended by appeal to two main arguments: first, an argument from philosophy of mind, according to which panpsychism is the only view which successfully integrates consciousness into the physical world (Strawson 2006; Chalmers 2013); second, an argument from categorical properties, according to which panpsychism offers the only positive account of the categorical or intrinsic nature of physical reality (Seager 2006; Adams 2007; Alter and Nagasawa 2012). ${ }^{1}$

Historically, however, panpsychism has also been defended by appeal to a third argument based on considerations about the nature and observability of causation. This argument has not been much discussed in recent times. Here is a concise version from William James:

... the concrete perceptual flux, taken just as it comes, offers in our own activity-situations perfectly comprehensible instances of causal agency ... If we took these experiences as the type of what actual causation is, we should have to ascribe to cases of causation outside of our life, to physical cases also, an inwardly experiential nature. In other words, we should have to espouse a so-called "pan-psychic" philosophy. (James 1911: 218)

James here suggests that we have direct experience of causation in our own agency. He thereby directly contradicts David Hume, who famously denied that we have any experience of causation. James goes on to claim that if this experience is representative of causation in general, it follows that all causation is mental, and that panpsychism is true.

This kind of argument for panpsychism can be called the argument from (experience of) causation. This chapter offers, first, a history of this argument and arguments closely related to it, and second, an analysis of the argument - is it valid, are its premises in any way defensible, and how does it relate to the other, more popular arguments for panpsychism from philosophy of mind and categorical properties?

\footnotetext{
${ }^{1}$ Historical defenders of the first type of argument include Leibniz (Monadology §17) and James (1890/1981: 151-2); see also Skrbina (2005) on the arguments from non-emergence and continuity for others. Historical defenders of the second kind of argument include Leibniz (see Pereboom 2015), Schopenhauer (see 1859/1966a: §24; 1859/1966b: ch. XVIII) and Eddington (see Strawson 2006).
} 


\section{Historical Proponents of the Argument}

\subsection{Leibniz}

G. W. Leibniz held that reality ultimately consists of mind-like substances called monads. Among his arguments for this view is the argument from causation: ${ }^{2}$

The clearest idea of active power comes to us from the mind. So active power occurs only in things which are analogous to minds, that is, in entelechies; for strictly matter exhibits only passive power. (Leibniz 1704/1981: 171)

I found then that [the nature of all substances] consists in force, and that from this there follows something analogous to sensation and appetite, so that we must conceive them on the model of the notion we have of souls. (Leibniz 1695/1989: 139)

Active power, for Leibniz, is the power to affect other substances, while passive power is the power to be affected. He holds that active power must belong to all substances, because, echoing Plato's Eleatic Stranger, "what does not act does not exist" (1691/1965: 470). ${ }^{3}$ He finds it self-evident that we experience active power in our own thinking and willing. To the suggestion that this might be denied, he responds that "nothing in the world appears to be more contrary to reason" (Leibniz 1698/1908: 126). He thinks we should not posit non-mental active power in other substances because we do not have as clear an idea (perhaps no idea at all) of non-mental power. He also adheres to the principle that nature does not make leaps, i.e., is everywhere continuous. We know from our own case that mental powers exist, but not that non-mental powers do, and there would be a discontinuity between mental and non-mental powers; therefore, he holds, we should not posit non-mental powers.

\subsection{Schopenhauer}

Arthur Schopenhauer held a dual-aspect panpsychist view, according to which from the outside, the world appears as representation (Vorstellung), but from the inside, it appears as will (Wille). ${ }^{4}$ The will is both mental and causal in nature. Like Leibniz, Schopenhauer holds that all things must have causal powers or be animated by forces. Furthermore, the only way to understand these powers or forces is by analogy with our own power to act. Specifically, Schopenhauer argues, all causation must be driven by a kind of motivation:

\footnotetext{
${ }^{2}$ Leibniz may have been the first philosopher to explicitly put forth the argument from causation. Giordano Bruno and Francis Bacon also connect causation to mentality, but their reasoning is less explicit - see Skrbina (2005).

${ }^{3}$ One might be surprised to hear this from Leibniz, who is known for his view that monads cannot be causally influenced by other monads. But Leibniz only denies the existence of transeunt or inter-substantial causation, i.e., causation between distinct monads. Immanent or intra-substantial causation, whereby one state of same the monad causes the next, is real and essential to his system.

${ }^{4}$ Schopenhauer repeatedly states that the will is not necessarily conscious, which may seem to show that he is at best a panprotopsychist and not a panpsychist. One reason to nevertheless interpret him as a panpsychist is that he does not seem to use the term consciousness (Bewusstseyn) to mean phenomenal consciousness, but rather to denote a mode of knowledge (see Schopenhauer 1859/1966b: 199).
} 
Only from a comparison with what goes on within me when my body performs an action from a motive that moves me, with what is the inner nature of my own changes determined by external grounds or reasons, can I obtain an insight into the way in which those inanimate bodies change under the influence of causes, and thus understand what is their inner nature. (Schopenhauer 1859/1966a: 125)

... from the law of motivation I must learn to understand the law of causality in its inner significance. Spinoza (Epist. 62) says that if a stone projected through the air had consciousness, it would imagine it was flying of its own will. I add merely that the stone would be right. (Schopenhauer 1859/1966a: 126)

\subsection{James}

William James was committed to panpsychism throughout large parts of his career. As we saw previously, James claims that if we experience causation in agency, then panpsychism may follow. In other work, he explicitly endorses that we really have such as experience:

... the recesses of feeling, the darker, blinder strata of character, are the only places in the world in which we catch real fact in the making, and directly perceive how events happen, and how work is actually done. (James 1902/1987: 448-9)

He continues:

Hume's criticism has banished causation from the world of physical objects, and "Science" is absolutely satisfied to define cause in terms of concomitant change ... The "original" of the notion of causation is in our inner personal experience, and only there can causes in the old-fashioned sense be directly observed and described. (James 1902/1987: 449, footnote 1)

In this passage, James explicitly points to the experience of agency as a response to Hume's famous query as to whether we have any impression (or experience) that matches our commonsense idea (or concept) of causal power. In later work, we find an elaborate discussion how this idea leads into the "region of panpsychic ... speculation" (1912: 189).

\subsection{Whitehead, Hartshorne and Others}

A. N. Whitehead developed a distinctive process-ontological version of panpsychism, according to which the fundamental components of reality are "occasions", i.e., events or instantiations, of experience. He argues that:

... in so far as we apply notions of causation to the understanding of events in nature, we must conceive these events under the general notions which apply to occasions of experience. For we can only understand causation in terms of our observations of these occasions. (Whitehead 1933/1967: 184).

Unlike other proponents of the argument, Whitehead does not focus on volition or motivation as the basis of our experience of causation, but rather on the relation between memories and perceptions and the events remembered or perceived. In this, he is followed by Charles Hartshorne, a subsequent process philosopher: 
Psychicalism [i.e., panpsychism] has the signal advantage, hinted at by Francis Bacon, ${ }^{[5]}$ that it can construe causal connectedness of events in terms of generalized concepts of memory and perception. Materialism and dualism lack these resources and are in Hume's predicament about causality. Memory and perception are effects whose causes are intrinsically given to them. These are our only clues to the intelligible connectedness of events. (Hartshorne 1977: ch. 3; see also Hartshorne 1954, 1973)

Other philosophers who have endorsed versions of the argument from causation include James Ward (1915: 172-173), G. F. Stout (1931, 1935) and Friedrich Schiller (1906, 1907). These philosophers mainly base their arguments on volition or motivation.

A similar argument for a weaker conclusion can be found with Isaac Newton. Newton often engaged in metaphysical speculation about the origin of the laws of motion and gravity and the nature of force. On the one hand, he considered whether they might originate directly from God. But he also considered whether laws and forces could be grounded in the powers we experience as underlying our own motion: "We find in ourselves a power of moving our bodies by our thoughts". From this, he infers: "we cannot say that all nature is not alive" (Newton in a draft of Opticks, transcribed in McGuire 1968: 171; see also Gabbey 2002). In other words, from the fact that we seem to experience causation in agency, Newton concludes that panpsychism is possibly true.

\section{Historical Proponents of the Reductio}

\subsection{Hume}

Historically, several philosophers have also put forth a modus tollens, or reductio ad absurdum, version of the argument - according to which one of the premises must be rejected because the panpsychist conclusion is unacceptable. One example is Hume himself:

It may be pretended, that the resistance which we meet with in bodies, obliging us frequently to exert our force, and call up all our power, this gives us the idea of force and power. It is this nisus, or strong endeavour, of which we are conscious, that is the original impression from which this idea is copied. But ... we attribute power to a vast number of objects, where we never can suppose this resistance or exertion of force to take place ... to inanimate matter, which is not capable of this sentiment ... It must, however, be confessed, that the animal nisus, which we experience, though it can afford no accurate precise idea of power, enters very much into that vulgar, inaccurate idea, which is formed of it. (Hume 1748/1999: 139, footnote 13)

Somewhat surprisingly, Hume here admits that we do have an impression to match our idea of causation. Yet, he claims that this impression does not match any accurate and precise idea. One of Hume's reasons for dismissing the impression is that it would lead to a conflict with the assumption that matter is not capable of sentiment; or in other words, that if the impression were accurate, it would entail panpsychism. He thereby affirms the validity of the argument from

\footnotetext{
${ }^{5}$ For Bacon's hint, see Skrbina (2005: 83)
} 
causation but opts to reject the premise that things have (knowable) causal powers rather than accepting the conclusion. ${ }^{6}$

This shows that, from the very beginning, reductionism about causation was not solely motivated by empiricism, as is often claimed, but also by resistance to panpsychism.

\subsection{Reid}

Thomas Reid was one of the earliest critics of Hume's view of causation. Reid argues that we know causal powers from the experience of agency, and furthermore, that only conscious beings could have them:

... of the manner in which a cause may exert its active power, we can have no conception, but from consciousness of the manner in which our own active power is exerted. (Reid 1788: 37)

Every thing we can discover in our own constitution leads us to think, that active power cannot be exerted without will and intelligence. (Reid 1788: 40-1)

One might think this would lead Reid to accept panpsychism, but this he considers primitive and unscientific (1788: 282-3). Instead, he rejects the premise that purely physical, non-conscious things have causal powers. How does he think purely physical things get by without their own causal powers? Reid concludes that they must be governed by the active power of God - another conscious being. In other words, he adopts a form of occasionalism with respect to the inanimate world.

\subsection{Newtonians}

In the days of Newtonian science, many scientists were dissatisfied with Newton's concept of force. As mentioned, Newton himself understood force in partially metaphysical terms. Many of his readers also engaged in extensive metaphysical speculation about the true nature of force (see Jammer 1957: ch. 8). On the other hand, many scientists came to see the concept as essentially anthropomorphic. They were therefore motivated to pursue a purely relational, mathematical definition of force - effectively endorsing the reductio (see Jammer 1957: ch. 11).

\subsection{4. Mach}

The scientist and philosopher Ernst Mach played an important role in the development of a relational reduction of force. He held that the concept of causation, which is linked to the metaphysically suggestive, unreduced concept of force, should be eliminated altogether, partly on the basis of its inherent anthropomorphism: ${ }^{7}$

\footnotetext{
${ }^{6}$ Many scholars regard Hume as an eliminativist about irreducible causal powers. But some, such as Strawson (1989) regard him as a skeptical realist, i.e., as affirming the (possible) existence of irreducible causal powers but denying that we can form any positive conception of their nature.

${ }^{7}$ This is somewhat curious, given that Mach endorsed a type of neutral monism that bordered on panpsychism (he took the neutral substrate to be pure experience). Perhaps it was only the kind of panpsychism that takes causation to be related to agency that he found objectionable.
} 
I hope that the science of the future will discard the idea of cause and effect, as being formally obscure, and in my feeling that these ideas contain a strong tincture of fetishism [i.e., animism, panpsychism], I am certainly not alone. The more proper course is, to regard the abstract determinative elements of a fact as interdependent, in a purely logical way, as the mathematician or geometer does. True, by comparison with the will, forces are brought nearer to our feeling; but it may be that ultimately the will itself will be made clearer by comparison with the accelerations of masses. ${ }^{[8]}$ (Mach 1897: 253-4)

\subsection{Collingwood}

Another eliminativist about causation is R. G. Collingwood. In his article "On the So-Called Idea of Causation", Collingwood claims:

In the first sense of the word cause, that which is caused is the free and deliberate act of a conscious and responsible agent, and "causing" him to do it means affording him a motive for doing it. (Collingwood 1937:

86)

This is "historically the original sense [of the word 'cause' ...] and remains strictly speaking the one and only 'proper' sense" (1937: 85). From this he concludes that Newton, with his distinction between caused (forced) and uncaused (inertial) motions, effectively advocated a "reduction of physics to social psychology" (1937: 105). Accordingly, he recommends that the concept of causation should be outright eliminated.

\subsection{Russell}

\section{Bertrand Russell, in his "On the Notion of Cause", argues:}

... the word "cause" is so inextricably bound up with misleading associations as to make its complete extrusion from the philosophical vocabulary desirable ... The law of causality, I believe, like much that passes muster among philosophers, is a relic of a bygone age, surviving, like the monarchy, only because it is erroneously supposed to do no harm. (Russell 1912: 1)

Part of the reason why the concept of causation is harmful is its connection with agency:

The importance of these considerations lies partly in the fact that they lead to a more correct account of scientific procedure, partly in the fact that they remove the analogy with human volition which makes the conception of cause such a fruitful source of fallacies. (Russell 1912: 9)

Russell does not explicitly claim that panpsychism constitutes or is involved in the fallacies in question, but it is a natural interpretation. ${ }^{9}$

\footnotetext{
${ }^{8}$ Interestingly, Schopenhauer takes the exact opposite view: “... if we refer the concept of force to that of will, we have in fact referred something more unknown to something infinitely better known, indeed to the one thing really known to us immediately and completely; and we have very greatly extended our knowledge. If, on the other hand, we subsume the concept of will under that of force, as has been done hitherto, we renounce the only immediate knowledge of the inner nature of the world that we have, since we let it disappear in a concept abstracted from the phenomenon, with which therefore we can never pass beyond the phenomenon" (Schopenhauer 1859/1966a: 111-112).

${ }^{9}$ At least at this point of Russell's career. Like Mach, Russell later endorsed neutral monism, a view very close to panpsychism. But the time of the publication of "On the Notion of Cause", he was one of neutral monism's staunchest critics.
} 


\section{Recent Proponents of the Reductio}

The argument from causation has not found many contemporary defenders, but the reductio has found quite a few. Since the decline of the anti-metaphysical influence of logical empiricism, nonreductionism about causation has been on the rise. Edward Madden and Peter Hare were early proponents of the revival of non-reductive causal powers metaphysics. They argue that we should reject the view that causation can only be experienced in agency because it leads to panpsychism:

It is most crucial to avoid what we like to call the "inferential predicament," because getting involved in it forces one inevitably into pan-psychism and animism, an unmitigated disaster in the eyes of a great majority of contemporary philosophers... . The inferential predicament arises by taking volitional contexts as the only ones in which causal power is directly perceived, and then projecting such experienced power onto objects and events in order to make sense of causal necessities in the physical world. (Madden and Hare 1971: 23)

The best, and perhaps only, way to avoid the inferential predicament and its pan-psychical consequence is to reject the premise that one is directly aware of causal power only in volitional situations. (Madden and Hare 1971: 25)

They proceed to argue that we are rather directly aware of causal power in the physical world.

David Armstrong is known for developing the view that causation is grounded in irreducible universal laws, as opposed to causal powers. He also endorses a version of the reductio, but takes it to indicate only the falsity of dispositionalism, i.e., realism about causal powers, as opposed to realism about irreducible laws:

... a disposition as conceived by a Dispositionalist is like a congealed hypothetical fact or state of affairs: 'If this object is suitably struck, then it is caused (or there is a certain objective probability of its being caused) to shatter.' It is, as it were, an inference ticket (as Ryle said), but one that exists in nature (as Ryle would hardly have allowed). That is all there is to a particular disposition. Consider, then, the critical case where the disposition is not manifested. The object still has within itself, essentially, a reference to the manifestation that did not occur. It points to a thing that does not exist. This must remind us of the intentionality of mental states and processes, the characteristic that Brentano held was the distinguishing mark of the mental, that is, their being directed upon objects or states of affairs that need not exist. This intentionality of the mental undoubtedly exists. But for physicalists such as myself it presents a prima facie problem. If the mental has intentionality, and if, as Brentano thought, it is also ontologically irreducible, then there is something here that would appear to falsify Physicalism. Physicalists about the mind are therefore found trying to give some ontologically reductive account of the intentionality of the mental. But if irreducible dispositions and powers are admitted for physical things, then intentionality, irreducible intentionality, has turned up in everything there is.

Is this not objectionable? Does it not assimilate the physical to the mental, rather than the other way around? (Armstrong 1997: 79, emphasis original)

Intentionality is the manner in which thoughts, actions and other mental phenomena can be about or directed toward other things. Armstrong observes that dispositions must also be conceived as directed toward something. Fragility, he says, refers or points to shattering. Similarly, we could think of electrons with the power of charge as referring, pointing, or perhaps aiming, toward 
repelling other electrons. Armstrong claims that if dispositions and powers are irreducible, they can only be understood as intentional and therefore mental, which he finds unacceptable. He concludes that dispositions and powers must be reducible to laws, which, on his view, have nothing to do with intentionality.

C. B. Martin and Karl Pfeifer consider a similar reductio based on the similarities between causation and intentionality. They argue:

... the most typical characterizations of intentionality ... all fail to distinguish intentional mental states from non-intentional dispositional physical states. Accepting any of these current accounts will be to take a quick road to panpsychism! (Martin and Pfeifer 1986: 531)

After surveying various accounts of intentionality, they assert:

Somewhat ironically, if we were to leave our discussion at this point, someone might interpret it as an argument for panpsychism, in that the characterizations of intentionality that we have discussed apply to anything (mental or physical) that has causal dispositions. For some, this may be a happy result - for us it is a reductio ad absurdum and an invitation to look elsewhere for an account of the intentional. (Martin and Pfeifer 1986: 551)

Martin and Pfeifer only take this as a reductio of a certain kind of account of intentionality. They think dispositionalism can be made compatible with physicalism by revising our account of intentionality.

\section{An Analysis of the Argument}

The argument from causation can be understood as having the following general form:

I. Non-reductionism: All physical things have causal powers.

II. Mental causation: The only causal powers whose nature we can know, or positively conceive of, are mental.

III. Non-skeptical realism: The nature of the causal powers of physical things is knowable, or positively conceivable.

Therefore,

IV. Panpsychism: All physical things have mental properties.

This argument seems valid. But are the premises defensible? Let us consider them one by one. 


\subsection{Premise I: Non-Reductionism}

Causal powers can be roughly defined as intrinsic properties in virtue of which causes produce or bring about their effects, or make them happen, and thereby metaphysically necessitate them. ${ }^{10}$ Note that causal necessitation is defeasible, not absolute: causes only necessitate their effects in the absence of interference from other causes, i.e., ceteris paribus.

On Hume's view, there is no such thing as causal powers (at least not as far as we know). On the Humean regularity view of causation, to say that one thing causes another is merely to say that things of the first kind happen to be regularly followed by the things of the second kind. Or in other words, causal regularities are metaphysically contingent, not necessary.

According to Premise I of the argument from causation, all physical things have causal powers. There are many different arguments that could support this view, but there is one which is especially relevant for the argument from causation. This is the very basic argument from appearances: causation appears (in our experience) to involve causal powers and we have no good reason to distrust this appearance.

Most reductionists and skeptics about causation, including Hume, agree that causes pretheoretically appear to necessitate their effects, but take this appearance to be illusory. According to Hume, all appearances of causal power are based on our own habits or subjective expectations that certain kinds of events always go together. Hume supports this via a link between conceivability and possibility. On Hume's view, if we really experience necessary connections between objects or events themselves, i.e., something in virtue of which it would be impossible for an effect not to occur given the cause (in the absence of interference), then it should also be inconceivable for the effect not to occur given the cause (in the absence of interference). But, Hume argues, we can conceive of any cause with or without any effect, which shows that we experience nothing in virtue of which their connection is necessary.

How can Premise I be defended against this Humean view? Some argue that we really do experience causal powers in the external, physical world (Michotte 1963; Anscombe 1971). But if Premise I is defended on this basis, there is a risk of undermining Premise II, according to which the only causal powers we can know, or positively conceive of, are mental.

Another option, that avoids this problem, is to rather defend Premise I on the basis of Premise II. Assuming we really experience our own causal powers in agency, as suggested by many philosophers discussed so far, this would show that some physical things, human beings, have causal powers. It does not follow from this that all physical things have them, as Premise I asserts. But it would be natural to suppose that all causation is of the same general metaphysical kind. It

\footnotetext{
${ }^{10}$ Given indeterminism, one might say causes necessitate some objective probability of their effects. I will set indeterminism aside here for the sake of simplicity.
} 
therefore seems arguable that if some causes necessitate their effects in virtue of causal powers, as per Premise II, then all causes do, as per Premise I.

Another way of defending Premise I would be to appeal to additional, more general arguments against the regularity theory. One such argument is that if causation is contingent, it would be great "cosmic coincidence" that the world is regular, which seems highly implausible for various reasons (see, e.g., Armstrong 1983; Strawson 1987). Note, however, that these arguments leave it open whether causes necessitate their effects in virtue of intrinsic causal powers of in virtue of extrinsic governing laws a la Armstrong.

\subsection{Premise II: Mental Causation}

Premise II says that the only kinds of causal powers whose nature we can know, or positively conceive of, are mental. This is the most central premise of the argument from causation, and also the most controversial. As noted, Hume takes inconceivability as a criterion of necessity. Taking this as a starting point, there are two available strategies for defending Premise II: (1) to argue that some mental properties, but no non-mental properties, are truly inconceivable without their effects; (2) to argue that Hume's criterion is too strong, and that we should rather adopt another criterion, which only mental properties can meet.

Several proponents of the argument from causation hold that in voluntary action, we experience ourselves as exerting will, and to exert will is to exert power. Several philosophers who would not support the panpsychist conclusion also hold a similar view (Locke 1689/1975: I.XXI.4, Searle 1983; Strawson 1992: ch. 9; Armstrong 1997).

Hume considers this view, but objects that we can easily conceive of willing, intending or trying to do something but where no action follows. This seems correct. In the case of physical action, it seems conceivable that someone tries to move their limbs, but their limbs refuse to move, in the absence of any interference from other causes. The same holds for mental action: for example, it seems conceivable that someone tries to solve a simple math problem, or tries to remember something, but the right solution or memory just fails to come to mind, without any interference. It therefore seems that willing, intending or trying cannot be defended as experiences of causal power via strategy (1); that is, they do not meet the inconceivability criterion.

But they could perhaps be defended by strategy (2); that is, by showing that they meet a weaker criterion. Even if we do not experience a strictly necessary connection between will and action, the experience of will might still seem to give a more direct experience of causal power than the experience of external, physical causation. Many philosophers have noted that our own actions are directly experienced as events that do not just passively happen to us; rather, it feels as though we actively bring them about (Ginet 1997; Bayne and Levy 2006; Horgan 2011). We do not inductively infer that some bodily events are actions caused by us (e.g., walking, raising an arm) while others are not (e.g., stumbling, having one's arm lifted by someone else); rather, it seems we can directly feel the difference. 
Some would argue that we can also sometimes non-inferentially detect physical causation, for example, there is a sense in which many mechanical interactions such as collisions just look causal (Michotte 1963). Such interactions could clearly conceivably be different, but if the conceivability criterion is relaxed for volition, it should arguably also be relaxed for physical causation. But the case for volition might still be stronger than the case for physical causes. Our ability to detect physical, non-volitional causation seems mostly limited to specific kinds of mechanical cases (such as solid objects colliding). In other contexts, it often goes wrong (for example, concerning action at a distance). It is also not highly reliable within the mechanical context: sequences that are not really causal can easily be set up to look causal. In contrast, our ability to distinguish our own actions from mere happenings seems much more general and reliable (that is to say, we are often wrong about the results of our actions, but not about whether or not we are acting at all), which suggests that we have a more immediate awareness of volitional causation. In further support of this, some empirical research suggests that our phenomenology of effort tends to accurately track our actual, physically measurable energy expenditure (Bayne and Levy 2006). We do not seem to have a similar ability to directly track external, physical energy transfer.

Some philosophers, notably Schopenhauer, hold that we experience causation in motivation. This proposal is different from the proposal just considered. Whereas will or agency can be understood as how agents exert causal power on the world, motives appear to exert causal power on the will or the agent. Motives appear to make us (try to) do things. Elsewhere (Mørch 2014, 2017, 2018, 2019), I have elaborated on this idea and argued that we experience necessary connections between motives such as pain and pleasure and efforts to avoid or pursue them. This is a connection which Hume did not consider and which may have a chance of passing his conceivability requirement, i.e., it might be defensible on the basis of strategy (1). It is hard to conceive of someone experiencing strong pain, but where this does not make them at least try to avoid it $^{11}$ - assuming the complete absence of interfering motives to endure the pain.

Other philosophers, including Whitehead and Hartshorne, argue that we experience causal powers via perception and memory. They claim that perceptions and memories present themselves not as causes, but rather as effects of the events they are perceptions and memories of. It is hard to see how this suggestion can be defended via strategy (1), because it seems clearly conceivable that perceptions and memories can be non-veridical. Whitehead and Hartshorne rather defend it via a version of strategy (2): they endorse a distinctive indeterministic metaphysics of causation, according to which the inconceivability criterion would not seem to apply (see Hartshorne 1973).

Even if it is granted that we really experience causal powers through our phenomenology of will, agency or motivation (from here I will set the proposal of memory and perception aside), it could

\footnotetext{
${ }^{11}$ Note that it might still be conceivable that these tryings or efforts do not lead to successful avoidance, as per Hume's objections discussed previously. In other words, the claim is that there is a necessary connection between motives (such as pain) and efforts (such as effort towards avoidance) understood as mental events, not between motives and successful physical actions.
} 
be objected that it does not follow that the causal powers we experience are mental. Perhaps our experiences of causal powers can be viewed as analogous to ordinary perception. In perception, we represent properties such as the color and size of an apple by means of mental, perceptual phenomenology. This does not mean that color and size are mental properties of the apple, and that all things with size and colors must have minds. Why should we not regard our phenomenology of will, agency or motivation in the same way; that is, as mental representations of non-mental causal powers?

One response is that the reason we take will and motivation to be mental is not because we represent them by mental phenomenology; rather, it is because will and motivation are mental in and of themselves. Will essentially involves intentionality, which, as noted previously, is widely regarded as a mark of the mental. Motives such as pain and pleasure, on the other hand, seem to affect our will in virtue of how they feel or what they are like for a conscious subject. If there is such a thing as unconscious or unfelt pain or pleasure, it would not affect the will in the same direct way. If this is correct, then the causal powers of will and motives cannot be separated from mentality in the way physical properties can be separated from our mental perceptual representations of them (Mørch 2014, 2018).

Another objection to Premise II is that even if the only causal powers we experience are mental properties, we can still conceive of non-mental causal powers. As mentioned, Armstrong holds that causal powers, while not reducible to contingent regularities, are fundamentally grounded in irreducible governing laws of nature. Can this give the basis for a non-mental conception of causal powers?

Etymologically, the concept of a law of nature is closely connected to both mental agency and causal powers. The concept of a law of nature was originally a legal metaphor-before the scientific revolution, the only concept of law was the concept of a rule imposed by human or divine agents, who would have the power to impose laws. But of course, the etymology of a concept does not necessarily determine its meaning. Armstrong proposes that that laws are to be understood as "relations between universals" (Armstrong 1978, 1983), a notion which does not seem to have any connection with the notion of agent-imposed laws. But one might wonder how Armstrong's view should be more precisely understood. Somewhat surprisingly, in view of his criticism of dispositionalism cited earlier, to clarify his concept of causation Armstrong at one point appeals to the experience of agency as well:

we have - in certain favourable cases - perception of forces acting on our bodies or our body exerting force on things, and perhaps also introspective awareness of the successful application of the will - direct or noninferential, awareness of singular ... causation. In Humean terms, there is an impression from which we derive the idea of causality. (Armstrong 1997: 216-17) 
He then claims that the concept of a law comes from bringing together this experience of causation and our experience of regularity. But if we experience our own will as mental, it is not clear how this could yield a wholly non-mental concept of a law.

Perhaps we can conceive of non-mental powers or laws on the basis of mental powers? One might think that from the concept of a mental power we can abstract away a general, non-mental concept of causal power (or law, but from here I will set the notion of irreducible laws aside). These kinds of causal powers could be posited throughout the physical world.

In response to this, panpsychists may argue that by abstracting away from the mental aspects of power we are left with no positive conception of power (Mørch 2014, 2018). It seems that all we can know about non-mental powers on this basis is that they are just like mental powers, but not mental. But if we take away the mental aspect of will and motivation, then arguably not much is left to conceive of: do we have any idea of what non-mental will or non-mental motives would be like, or how they may enforce necessary connections or make things happen? Non-panpsychists must respond either by explicating the positive content of their conception of non-mental power, or by arguing that there is nothing wrong with positing non-mental powers of whose nature we have no positive conception. The latter option may seem more promising. But this option is ruled out by Premise III of the argument from causation, to which we now turn.

\subsection{Premise III: Non-Skeptical Realism}

Premise III says that the nature of the causal powers of physical things is knowable, or positively conceivable. This premise is denied by proponents of skeptical realism about causation, i.e., the view that all physical things have irreducible causal powers, but we are completely ignorant about the nature of these powers. That is to say, all we know (roughly) about causal powers is that they ground necessary connections between causes and effects, but we have no positive grasp of how they do so or what they are otherwise like. Someone who accepts Premises I (all physical things have causal powers) and II (only mental causal powers can be positively conceived of) of the argument from causation could nevertheless avoid panpsychism by adopting skeptical realism about physical causal powers.

How can the panpsychist respond to the skeptical realist? It would be hard to defend the general thesis that if things have causal powers, then their nature must be conceivable by us. There is no clear reason why reality should be limited to what we humans can know and conceive of. Hume and James both (at times) expound meaning empiricism, the view that concepts without positive content derived from concrete experiences are meaningless. ${ }^{12}$ Given meaning empiricism, it would

\footnotetext{
${ }^{12}$ As Hume claims: "If we have really no idea of a power or efficacy in any object, or of any real connexion betwixt causes and effects, it will be to little purpose to prove, that an efficacy is necessary in all operations. We do not understand our own meaning in talking so" (Hume 1739-40/2000). This is echoed by James: "Everything real must be experienceable somewhere, and every kind of thing experienced must somewhere be real. ... By the principle of pure experience, either the word 'activity' must have no meaning at all, or else the original type and model of what it means must lie in some concrete kind of experience that can be definitely pointed out" (James 1912: 160). He continues: "If
} 
be meaningless to assert Premise I, i.e. that all things have causal powers, while denying Premise III, i.e., that we have a positive concept of causal powers from experience. However, meaning empiricism is a highly controversial view, and perhaps something panpsychists especially should be wary of accepting anyway, as it risks undermining a whole host of metaphysical concepts that may be necessary for articulating other aspects of the view.

Yet, if Premise II is already granted, i.e., that some things have mental causal powers whose nature we do know, there is a case to be made for Premise III which does not presuppose meaning empiricism. As we saw earlier, Leibniz invokes a principle of the continuity of nature. Given such a principle, we should not posit non-mental, but otherwise unknown, powers because they would be discontinuous with mental powers. Another helpful principle is the principle of qualitative parsimony: do not posit more fundamental kinds of properties and entities than you need in order to account for your observations. Given this principle, we should not posit two kinds of powers, mental and non-mental, when we can make do with only mental ones to account for our observations (recall, according to Premise II, there are no observations of non-mental powers).

But the best option may be to appeal another, general methodological principle: we should never reject adequate, positive theories merely because there are other theories in terms of unknowable, inconceivable properties which cannot be ruled out. For example, we cannot rule out that there is some theory that no human could ever positively grasp that explains gravity much better than general relativity theory. This does not seem like a good reason to reject the theory of general relativity. In the same way, one might argue, panpsychism gives us an adequate, positive theory of causation which should not be rejected in favor of the purely negative theory that there are unknowable powers.

\section{Other Arguments for Panpsychism}

How does the argument from causation fit with the other, more commonly discussed arguments for panpsychism from philosophy of mind and categorical properties?

The argument from causation seems fully compatible with the argument from philosophy of mind. In philosophy of mind, it has been argued that panpsychism can avoid the main problems of both physicalism and dualism at once (Alter and Nagasawa 2012; Chalmers 2013). The argument from causation can be regarded as further supporting the claim that it avoids the problem of dualism is particular. Dualism's main problem is the problem of mental causation: how can mental properties be causally relevant to the physical? The argument from causation further assures us that panpsychism does not face this problem by providing a more detailed picture of how panpsychist

\footnotetext{
we suppose activities to go on outside of our experience, it is in forms like these that we must suppose them, or else give them some other name; for the word "activity" has no imaginable content whatever save these experiences of process, obstruction, striving, strain, or release, ultimate qualia as they are of the life given us to be known" (James 1912: 167).
} 
mental causation would work. According to the argument, physical properties can only be causally efficacious in virtue of mental powers, and these mental powers relate to physical relations in a way analogous to how our will and motivation relate to our physical behavior.

The argument from causation may seem less compatible with the argument from categorical properties (Seager 2006; Alter and Nagasawa 2012). This argument can be construed as follows:

I). Categoricalism: All physical things have categorical properties.

II. Mental categoricity: The only categorical properties whose nature we can know, or positively conceive of, are mental.

III. Non-skeptical realism: The nature of the categorical properties of physical things is knowable or positively conceivable.

Therefore,

IV. Panpsychism: All physical things have mental properties.

Categorical properties are often understood as the opposite of dispositional properties, such as causal powers. Proponents of the argument from categorical properties often argue that all mental properties are categorical, and if categorical and dispositional properties are indeed opposites, this would rule out that any mental properties, such as motivational or volitional properties, are dispositional, as per the argument from causation.

One way to resolve this conflict would be to deny that all mental properties are categorical, i.e., to claim that motivational or volitional properties are purely dispositional and not categorical, whereas other mental properties (such as sensory phenomenology) are purely categorical. But it might be hard to defend that different kinds of phenomenal properties are that radically metaphysically discontinuous. A better alternative would be to reject the assumption that categorical and dispositional properties are opposite fundamental kinds. Some philosophers (Martin and Heil 1999; Strawson 2008) defend the view that all properties necessarily have both dispositional and categorical aspects, and that categorical and dispositional properties are actually identical. By assuming the identity view, the argument from categorical properties and the argument from causation can be reconciled in a more elegant and plausible way.

Given the identity view, the argument from causation will appear very similar to the argument from categorical properties, and one might worry it would therefore be dialectically superfluous. But the argument has at least one distinct dialectical advantage. Premise I of the argument from categorical properties, according to which all physical things have categorical properties, is often defended by appeal to the principle that dispositions need categorical grounds. But this principle is rejected by the aforementioned dispositionalists, according to whom all properties are irreducibly dispositional and do not need categorical grounds (Mumford 2006). It is not clear how panpsychists can defend 
Premise I of the argument from categorical properties against this claim. However, given the argument from causation, no such defense is needed. If the argument is sound, dispositionalism entails panpsychism.

\section{Conclusion}

The argument from causation is important both for the history of panpsychism and, in its reductio version, the history of reductionism about causation. Now might be the right time for its revival. In the current debate, panpsychism can no longer be dismissed as absurd, so the reductio in support of reductionism (or the denial of some other aspects of the premises) can be turned on its head in order to further support panpsychism.

As we have seen, the argument can be construed as having a valid form. The premises are all highly controversial, but still defensible. The most controversial premise is the premise that the only kinds of causal powers whose nature we can know, or positively conceive of, are mental. This can be defended by appeal to unique features of our phenomenology of will, agency and motivation. But more work is still needed to fully develop and assess this idea.

The argument makes a distinctive contribution to the debate about panpsychism, especially as a response to the challenge from dispositionalism to the argument from categorical properties. It may also contribute to debates within the metaphysics of causation, where non-reductionism about causal powers is a widespread view, but no clear response is to be found to Hume's challenge of how to positively conceive of their nature. The argument from causation shows that a strong and straightforward response may be found with panpsychism. ${ }^{13}$

${ }^{13}$ I would like to thank John Morrison and Galen Strawson for helpful comments on this chapter. 


\section{References}

Adams, Robert (2007). 'Idealism Vindicated'. In D. Zimmerman and P. van Inwagen (eds.), Persons: Human and Divine. Oxford: Oxford University Press, pp. 35-54.

Alter, Torin, and Nagasawa, Yujin (2012). 'What Is Russellian Monism?’ Journal of Consciousness Studies, 19 (9-10): 67-95.

Anscombe, G. E. M. (1971). Causality and Determination: An Inaugural Lecture. Cambridge: Cambridge University Press.

Armstrong, David M. (1978). A Theory of Universals: Universals and Scientific Realism, vol. II. Cambridge: Cambridge University Press.

Armstrong, David M. (1983). What Is a Law of Nature? Cambridge: Cambridge University Press. Armstrong, David M. (1997). A World of States of Affairs. Cambridge: Cambridge University Press.

Bayne, Tim, and Neil Levy (2006). 'The Feeling of Doing: Deconstructing the Phenomenology of Agency'. In N. Sebanz and W. Prinz (eds.), Disorders of Volition. Cambridge, MA: MIT Press.

Chalmers, David J. (2013). 'Panpsychism and Panprotopsychism'. The Amherst Lecture in Philosophy 8 (1-35). www.amherstlecture.org/chalmers2013. (Reprinted in G. Brüntrup and L. Jaskolla (eds.), Panpsychism. Oxford: Oxford University Press, pp. 19-47).

Collingwood, R. G. (1937). 'On the So-Called Idea of Causation'. Proceedings of the Aristotelian Society, New Series, 38: 85-112.

Gabbey, Alan (2002). 'Newton, Active Powers, and the Mechanical Philosophy'. In I. B. Cohen and G. E. Smith (eds.), The Cambridge Companion to Newton. Cambridge: Cambridge University Press.

Ginet, Carl (1997). 'Freedom, Responsibility, and Agency'. The Journal of Ethics, 1 (1): 85-98. Hartshorne, Charles (1954). 'Causal Necessities: An Alternative to Hume'. The Philosophical Review, 63 (4): 479-99.

Hartshorne, Charles (1973). 'Creativity and the Deductive Logic of Causality'. Review of Metaphysics, 27 (1): 62-74.

Hartshorne, Charles (1977). 'Physics and Psychics: The Place of Mind in Nature'. In J. B. Cobb and D. R. Griffin (eds.), Mind in Nature: The Interface of Science and Philosophy. New York: University Press of America. 
Horgan, Terry (2011). 'The Phenomenology of Agency and Freedom: Lessons from Introspection and Lessons from Its Limits'. Humana Mente, 15: 77-97.

Hume, David (1739-40/2000). A Treatise of Human Nature. Ed. J. Cottingham. Oxford Philosophical Texts. Oxford: Oxford University Press.

Hume, David (1748/ 1999). An Enquiry Concerning Human Understanding. Ed. T. L. Beauchamp. Oxford: Oxford University Press.

James, William (1890/1981). The Principles of Psychology, vol. 1. Ed. F. H. Burkhardt, F. Bowers, and I. K. Skrupskelis. The Works of William James, vol. 8. Cambridge, MA and London: Harvard University Press.

James, William (1902/1987). The Varieties of Religious Experience. Ed. B. Kuklick. William James: Writings 1902-1910. New York: Library of America.

James, William (1911). Some Problems of Philosophy: A Beginning of an Introduction to Philosophy. New York, London, Bombay and Calcutta: Longmans, Green \& Co.

James, William (1912). 'The Experience of Activity'. In James's Essays in Radical Empiricism. New York, London, Bombay and Calcutta: Longmans, Green \& Co.

Jammer, Max (1957). Concepts of Force: A Study in the Foundations of Dynamics. Cambridge, MA: Harvard University Press.

Leibniz, Gottfried Wilhelm (1691/1965). 'De Primae Philosophiae Emendatione, Et De Notione Substantiae'. In C. I. Gerhardt (ed.), Die Philosophischen Schriften. Hildesheim: G. Olms.

Leibniz, Gottfried Wilhelm (1695/1989). 'A New System of the Nature and Communication of Substances, and of the Union of the Soul and Body'. In R. Ariew and D. Garber (eds.), G. W. Leibniz: Philosophical Essays. Indianapolis: Hackett Publishing Company.

Leibniz, Gottfried Wilhelm (1698/1908). 'On Nature in Itself'. In G. M. Duncan (ed.), Philosophical Works of Leibnitz. New Haven: The Tuttle, Morehouse \& Taylor Company. Leibniz, Gottfried Wilhelm (1704/1981). New Essays on Human Understanding. Ed. and Trans. P. Remnant and J. Bennett. Cambridge and New York: Cambridge University Press.

Locke, John (1689/1975). An Essay Concerning Human Understanding. Ed. Peter H. Nidditch. Oxford: Clarendon Press.

Mach, Ernst (1897). Popular Scientific Lectures. Trans. T. J. McCormack. Chicago: The Open Court Publishing Company.

Madden, Edward H., and Hare, Peter H. (1971). 'The Powers That Be'. Dialogue, 10 (1): 12-31. 
Martin, C. B., and Heil, John (1999). 'The Ontological Turn'. Midwest Studies in Philosophy, 23 (1): 34-60.

Martin, C. B., and Pfeifer, Karl (1986). 'Intentionality and the Non-Psychological'. Philosophy and Phenomenological Research, 46 (4): 531-54.

McGuire, James E. (1968). 'Force, Active Principles, and Newton's Invisible Realm'. Ambix, 15 (3): 154-208.

Michotte, Albert (1963). The Perception of Causality. Oxford: Basic Books.

Mørch, Hedda Hassel (2014). Panpsychism and Causation: A New Argument and a Solution to the Combination Problem. Doctoral Dissertation, Department of Philosophy, Classics, History of Art and Ideas, University of Oslo, Oslo.

Mørch, Hedda Hassel (2017). 'The Evolutionary Argument for Phenomenal Powers'.

Philosophical Perspectives, 31 (1): 293-316.

Mørch, Hedda Hassel (2018). ‘Does Dispositionalism Entail Panpsychism?' Topoi, https://doi.org/10.1007/s11245-018-9604-y

Mørch, Hedda Hassel (2019). 'Phenomenal Knowledge Why: The Explanatory Knowledge Argument Against Physicalism'. In S. Coleman (ed.), The Knowledge Argument. Cambridge: Cambridge University Press.

Mumford, Stephen (2006). 'The Ungrounded Argument'. Synthese, 149 (3): 471-89.

Pereboom, Derk (2015). 'Consciousness, Physicalism, and Absolutely Intrinsic Properties'. In T. Alter and Y. Nagasawa (eds.), Consciousness in the Physical World: Perspectives on Russellian Monism. Oxford: Oxford University Press.

Reid, Thomas (1788). Essays on the Active Powers of Man. Edinburgh: John Bell and London: G. G. J. \& J. Robinson.

Russell, Bertrand (1912). 'On the Notion of Cause'. Proceedings of the Aristotelian Society, 13: $1-26$.

Schopenhauer, Arthur (1859/1966a). The World as Will and Representation. Trans. E. F. J. Payne, vol. 1. New York: Dover.

Schopenhauer, Arthur (1859/1966b). The World as Will and Representation. Trans. E. F. J. Payne, vol. 2. New York: Dover.

Seager, William (2006). 'The “Intrinsic Nature” Argument for Panpsychism'. Journal of Consciousness Studies, 13 (10-11): 129-45. 
Searle, John R. (1983). Intentionality: An Essay in the Philosophy of Mind. Cambridge:

Cambridge University Press.

Skrbina, David (2005). Panpsychism in the West. Cambridge, MA: MIT Press.

Stout, G. F. (1935). 'Mechanical and Teleological Causation'. Proceedings of the Aristotelian

Society, Supplementary Volume, 14 (1): 46-65.

Strawson, Galen (1987). 'Realism and Causation'. The Philosophical Quarterly, 37 (148): 25377.

Strawson, Galen (1989). The Secret Connexion: Causation, Realism and David Hume. Oxford: Oxford University Press.

Strawson, Galen (2006). 'Realistic Monism: Why Physicalism Entails Panpsychism'. Journal of Consciousness Studies, 13 (10-11): 3-31.

Strawson, Galen (2008). 'The Identity of the Categorical and the Dispositional'. Analysis, 68 (4): 271-82.

Strawson, P. F. (1992). Analysis and Metaphysics: An Introduction to Philosophy. Oxford: Oxford University Press.

Whitehead, Alfred North (1933/1967). Adventures of Ideas. New York: The Free Press. 